\title{
Anuran fauna of Bastar Division of Chhattisgarh state, India
}

\section{Sushil Kumar Dutta*}

Department of Zoology, Govt PG College, Jagdalpur, Bastar, Chhattisgarh, India 494001

Study Area: Bastar, Chhattisgarh, India.

Coordinates: $17^{\circ} 46^{\prime}$ to $20^{\circ} 34^{\prime} \mathrm{N}$ and $80^{\circ} 15^{\prime}$ to $82^{\circ}$ or E

Key words: Frog, Toad, Biodiversity

\section{Abstract}

Bastar is the southernmost civil division of Chhattisgarh state in India. Amphibian fauna of this sparsely populated tribal division is poorly known. The present piece of work has mainly been focused to tabulate the amphibian fauna of Indravati Basin so as to provide a base line data for more intensive studies of this group in the basin, lying mostly in the southern part of Chhattisgarh state. The present study evidenced 16 species belonging to 10 genera and 5 families of the order Anura from the Indravati basin. Habitats of each observed species has been briefed and in some cases the apparent morphological divergences have also been discussed.

\section{Introduction:}

As per the recent reports, there are 7,430 species of amphibians identif ied out of which 6,549 are Anura (frogs and toads), 676 are Caudata (newts and salamanders), and 205 are Gymnophiona (caecilians) (http://amphibiaweb.org/search/). Day by day the increasing interest to know the existing species of different groups of organisms bringing into limelight various new species, following the same the number of amphibian species increased over $60 \%$ since the year 1985 . In the present scenario, as per Biju (2008) 272 species of amphibians are exist in India while Dinesh et al., (2009) have prepared a systematic list of Indian amphibians mentioning 3 orders, 14 families, 47 genera and 299 species.

Till date very little attention has been paid to this group, in the Chhattisgarh state, especially over Bastar plateau and its associated Indravati basin. The works of Annadale (1909), Boulenger $(1882,1890,1920)$ and Parker (1934) contains no information of the amphibians of Bastar. However, the first available report in this topic was of Sayal etal. (1991), who reported seven species of amphibians from the erstwhile of then Bastar district, which is

*Author: dutta.sushil@yahoo.com 
divided in to seven districts as per new political scenario. Dutta (1992) has mentioned 14 amphibian species distributed in earlier Madhya Pradesh, of which 10 species have been mentioned to have their distribution within the area of erstwhile Bastar district of Chhattisgarh state. Chanda (1995) reported eight species of amphibians belonging to six genera and four families from Indravati Tiger Reserve of Bijapur district (earlier part of Bastar district). Biswas (2010) and Biswas \& Shrotriya (2011) identified the fungoid frog Hydrophylax malabaricus, (now Hylarana malabarica) as a cave frog from various caves of Kanger Valley National Park area, of Bastar district. Daniel \& Verma (1963) reported Kaloula taprobanica and Daniel \& Selukar (1963) reported Rana malabarica (now Hylarana malabarica) from Jagdalpur, Bastar district while ten amphibian species have been listed by Chandra \& Gajbe (2005) from Bastar district. Thus, overall eleven species of amphibians were already reported so far from Bastar district (now Bastar division) by different workers. This is one of our efforts to compile this information and to update the checklist of amphibians of this region.

\section{Materials and methods:}

Study Area and Sites: present study was carried out in Indravati Basin of Bastar (administrative) division of Chhattisgarh state, from 2006 to 2010. Bastar division is located in the southern part of Chhattisgarh state. The division is bound by the states of Orissa on its East, Maharashtra in West and Andhra Pradesh on its South. Bastar division is situated between latitudes $17^{\circ} 46^{\prime}$ to $20^{\circ} 34^{\prime} \mathrm{N}$ and longitudes $80^{\circ} 15^{\prime}$ to $82^{\circ} \mathrm{O} 1^{\prime} \mathrm{E}$, with altitudes ranging from 150 to 1200 meters above sea level. Currently, the division incorporates seven districts namely North Bastar (Kanker), Narainpur, Bastar, Kondagaon, South Bastar (Dantewada), Sukmaand Bijapur.

Bastar division is spread in an area of about $39,060 \mathrm{sq} . \mathrm{km}$. The length of Bastar division is $402 \mathrm{~km}$ from North to South and $360 \mathrm{~km}$ from East to West. Out of total area of the division, $23138 \mathrm{sq}$. km. (59.15\%) is under forest cover. Its forests form nearly $19.03 \%$ of the total forests in the state. The area has two National Parks, Kanger Valley (Bastar district) and Indravati Tiger Reserve (Bijapur district). However, only $21.6 \%$ of the area of the division is under cultivation. The land is undulating, rocky and infertile due to which the cultivation is poor. Bastar-plateau region comes under moist, sub-humid agro-climatic region of Chhattisgarh. The average annual rainfall of this region is $1380 \mathrm{~mm}$, most of which $(85 \%)$ is received from third week of June to mid September and remaining during February, March, May and October. May is the hottest and January is the coldest month of the year. The maximum temperature goes as high as $400 \mathrm{C}$ during the May and minimum as low as $30 \mathrm{C}$ during January. Atmospheric humidity is high from June to October. The climatic condition of the region is mild round theyear.

Data Collection: survey was carried out by direct search method during both day and night times. Search was carried out by turning boulders, prodding the litter, thoroughly searching the streams and crevices in stream banks. Persons forming the survey party remained unchanged throughout the study period. Habitats like Lake, Pond, River, Stream, Ditches, 
Forest, Caves, Cow dung pits and litter pits, Fallow land and Agriculture field were surveyed for spotting theamphibians.

Both still and video photographs were taken in the field as well as in the laboratory. Recordings of calls have been made for most of the species. Specimens were identif ied, as far as possible, in the field. Unidentified specimens were identified either in living condition using published keys for bufonids and ranids by: Boulenger (1890) Daniel (1963a, b; 1975, 2002) Daniel and Sekar (1989), Dutta (1997b), Chanda (2002) and Daniels (2005).

\section{Observations and Discussion:}

During study we identified 16 species belonging to 10 genera and 5 families of the order Anura from the Indravati basin. The classification and names are tabulated as per Frost (2009).

\section{Anurans of Indravati Basin:}

Class Amphibia Gray;

Order Anura FischerVon Waldheim

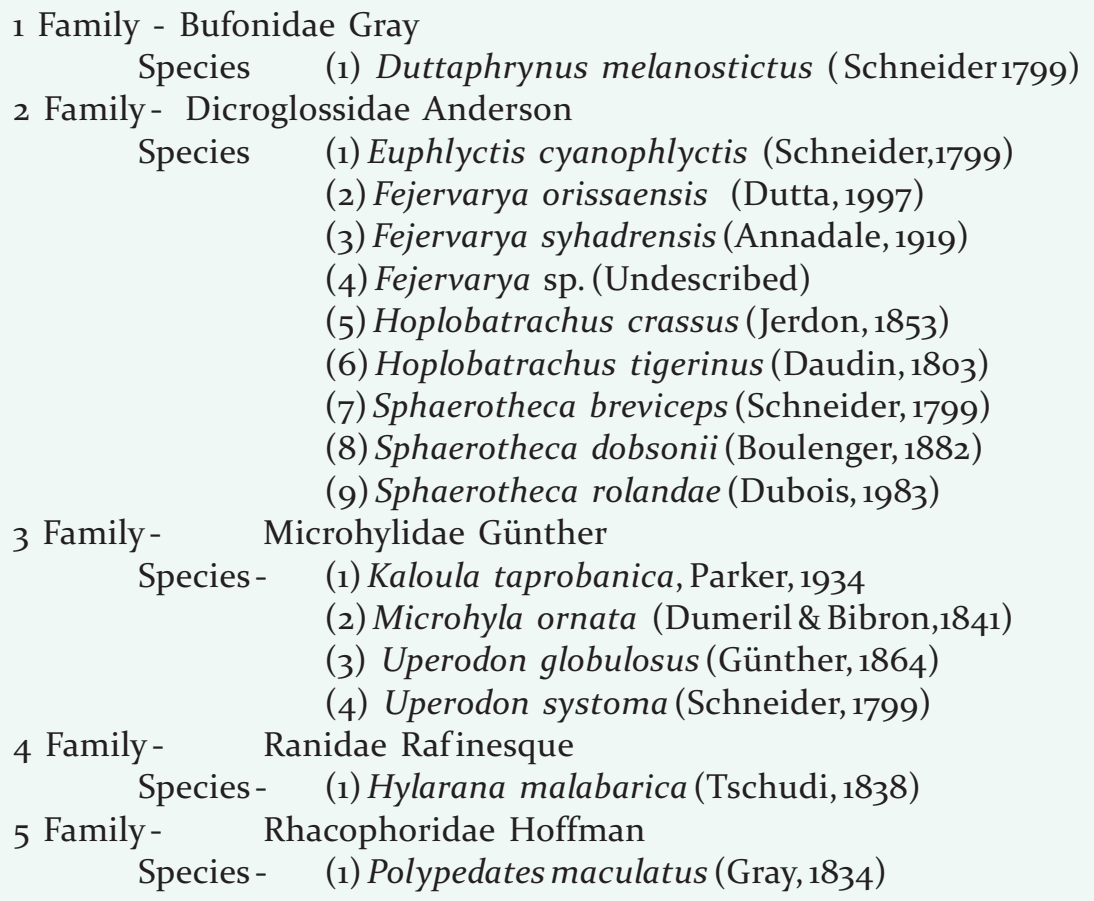

Out of 16 species, Fejervarya orissaensis (Dutta, 1997a), F. syhadrensis (Annadale, 1919), Fejervarya sp. (Undescribed), Hoplobatrachus crassus (Jerdon, 1853), Sphaerotheca dobsonii (Boulenger, 1882), Sphaerotheca rolandae (Dubois, 1983) and Uperodon systoma (Schneider, 1799) have not been reported earlier from the Indravati Basin.

Details of morphology, habit and habitat of all the species were recorded with their distribution in Indravati Basin, particulary the Bastar Division and activity pattern is being given in the given figure. 
The most abundantly reported family was Dicroglossidae $(56.25 \%)$, with 9 species, followed by Microhylidae (25.00\%) with 4 species and Bufonidae $6.25 \%$, Ranidae $6.25 \%$ and Rhacophoridae $6.25 \%$ with 1 species each.

The species Duttaphrynus melanostictus appear to be very widely distributed throughout the study area. This species was found highly adaptive to varied types of terrestrial habitats including the

Figure 1: Habitat of species recorded

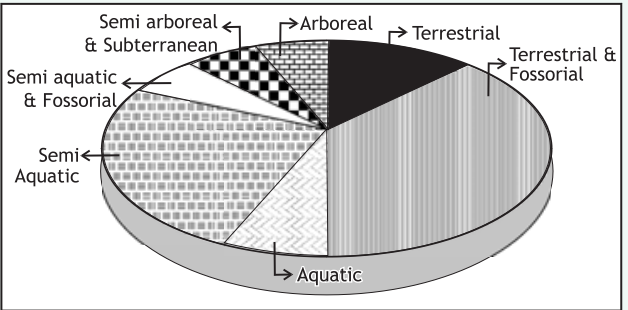
semi arid urban conditions. It appears to have acclimatized with spreading colonization and human interference.

Euphlyctis cyanophlyctis was abundant in all the water bodies of the study area, ranging from clear to highly polluted water. An amplecting pair of this species was observed in the month of March and some tadpoles were observed in the month of April, of the pre-monsoon season of the area. The

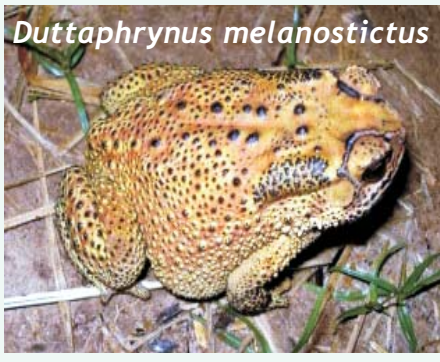
observation supports McCann (1932) and Mohanty-Hejmadi and Dutta (1977) about the possibility of Euphlyctis cyanophlyctis breeding at times, other

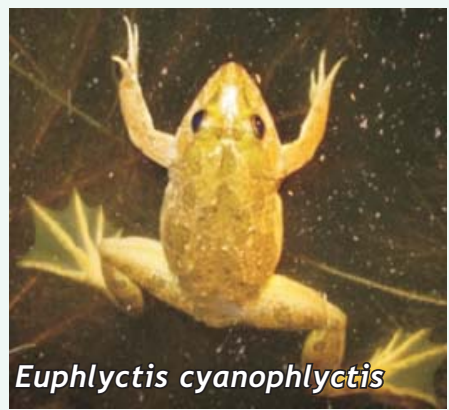
than monsoon months, under suitable circumstances.

Fejervarya is the most diversified group of species we identif ied in our study. Dutta (1997a) described a new species of the genus Fejervaryafrom Odisha, India; Fejervarya orissaensis. This species was found to be an abundant species of frog in the present study. Colour (in life) of the species was noted to be dorsum brown, grey or brick red and with or without yellowish narrow or wide vertebral band extending from tip of snout to vent. However, a green form, without a vertebral band, so far not reported, even by Dutta (1997a), was collected from Matagudi area, in the northwest side of Jagdalpur city. This form was also conf irmed to be the same species by Prof. S.K. Dutta (Personal communication).

The species Fejervarya syhadrensis is known to have a wide geographic distribution including India, Nepal and Pakistan (Chanda, 2002; Daniels, 2005) and was observed to be the most abundant species, also, during the present study. Sekar (1992) and Daniels (2005) have described the call of Fejervarya syhadrensis as resembling a ' bleating sheep', however, during present studies it was recorded as the loud clatter of castanets or the loud clatter of a typewriter-trr trr trr trr. trr trr....

A new form of Fejervarya was also observed during the study. The species will be given soon a separate taxonomical status by Prof. S. K. Dutta (Personal communication).

The genus Hoplobatrachus was represented by two species,

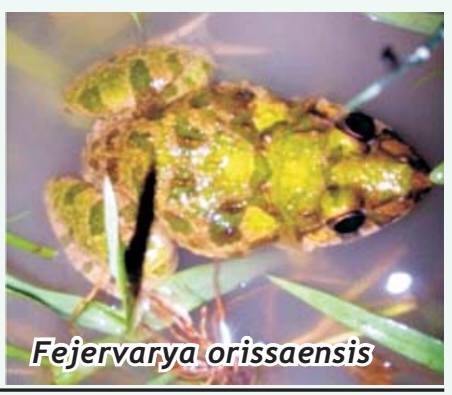

Ambient Science (2015)

http://www.caves.res.in/

Vol.-02(2): p-34 
Hoplobatrachus crassus and $H$. tigerinus. The species $H$. crassus was collected only from waterlogged and paddy fields in sympatry with $H$. tigerinus. This species resembles very close to $H$. tigerinus and can be only distinguished by its shorter legs and the presence of distinct and crescentic inner metatarsal tubercle or digging apparatus. This is not a rare species of the study area. This is a fossorial species and appears during summer monsoon. The species H.tigerinus has wide distribution throughout South Asia (Dutta, 1997b). The species was recorded to have maximum size and weight among all the amphibians recorded from the study area. This species was more commonly found on the banks of pool, ponds, rivers and marshes concealing in grasses and other herbaceous vegetation. Males of this species, at breeding congregations, are

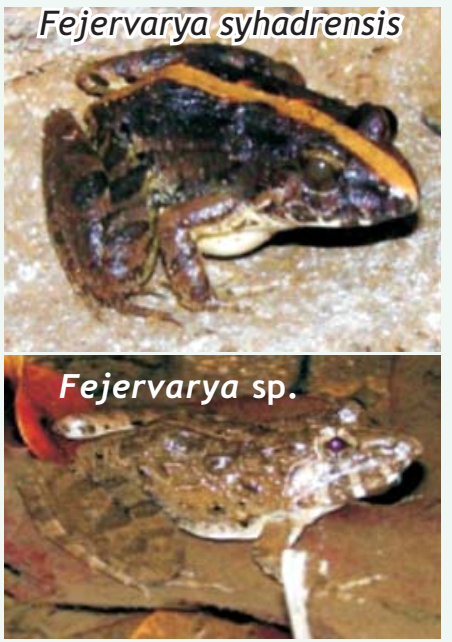

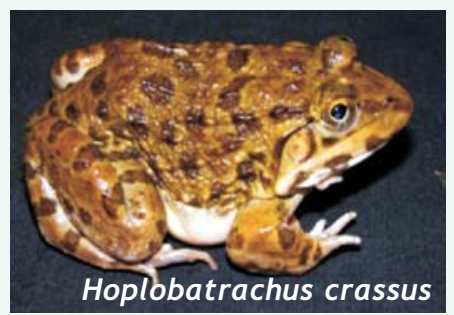

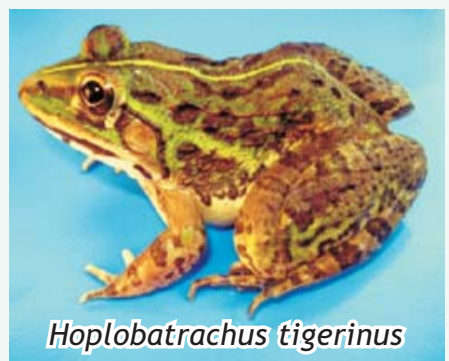
bright yellow. This colour changes to a sombre brown if the animal is removed elsewhere. The females and young males have sombre brown colour, although they also undergoes aestivation, underground, similar to the adult male. Based on this fact once McCann (1932) has argued that light could not be the reason for yellow colour. Then, what is it that brings about this striking change in their colouring? The question is still unanswered.

The genus Sphaerotheca was represented by 3 species, Sphaerotheca breviceps, S.dobsonii and S.rolandae. All are smallmedium sized frogs, terrestrial with burrowing and nocturnal habits. Each species has a strong compressed, crescentic, shovel-shaped, sharp edged, large inner metatarsal tubercle for digging. These are obligatory burrower and except for the breeding months they remain underground. During breeding months, which is the months of June to August in studies area, they are found on the ground. During post breeding seasons, they migrate to areas suitable for their burrowing life.

Sphaerotheca breviceps, and S.rolandae were found widely distributed in open forest and cultivation. Some specimens of S.rolandae were identified from the cultivated fields having

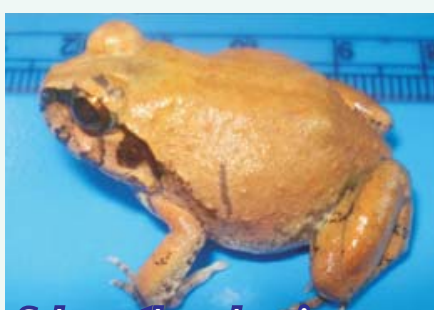

Sphaerotheca breviceps

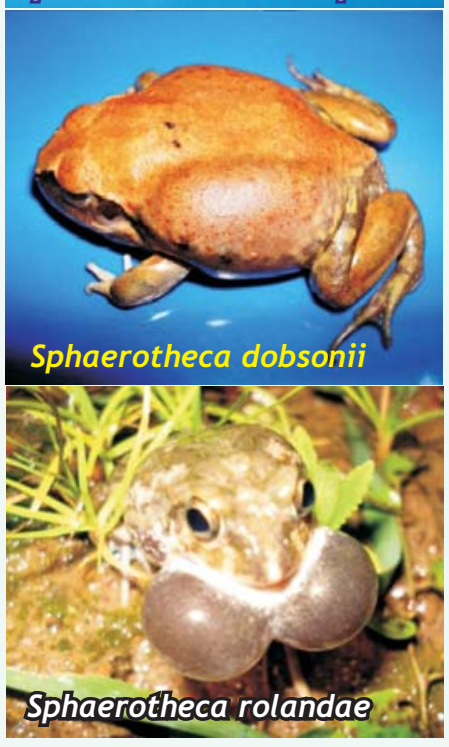

Vol.-02(2): p-35 
loose sandy soil while ploughing the field in the month of September where as S.dobsonii Specimens were seen in the forest floors during pre monsoon and monsoon seasons.

Microhyla ornata with only $20 \mathrm{~mm}$ snout to vent length was the smallest frog among all the species found in the study area. This was also a common species, recorded from moist thick grass, underneath of herbaceous vegetation and leaf litter in abundance. After heavy shower the individuals were found to congregate around ephemeral water bodies for reproduction.

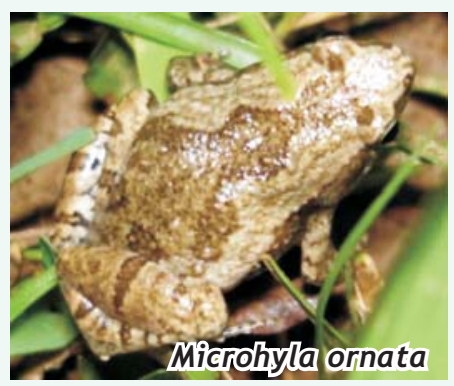
Tadpoles are transparent in appearance and have a distinguishing, diamond shaped mark on the head.

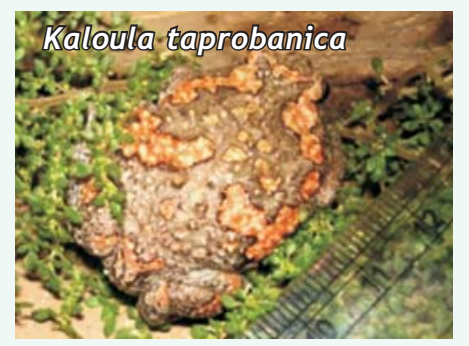

Kaloula taprobanica is basically a fossorial species but during breeding season, together with its congregation near ephemeral water bodies it has been collected also from tree trunk up to a height of about 2 m and on the drain pipes up to 3-4 $\mathrm{m}$ height. During present investigations a female of this species with $58 \mathrm{~mm}$ snout to vent length was recorded, while the maximum length, reported by Daniel (2002) is $40 \mathrm{~mm}$.

The genus Uperodon was represented by 2 species, Uperodon globulosus and Uperodon systoma.

Both species though larger in size, are very diff icult to locate due to their burrowing habit and cryptic nature. They are excellent burrowers, when disturbed, these frogs are capable of inflating themselves into a balloon; the globular shape is partly due to the enormously distensible lungs. The skin exudes a sticky secretion when the animal is kept above the soil. On land they move with short hops or a slow walk. In water they float and are at best feeble swimmers. Similar behaviour have been reported for the species by Dutta \& Pradhan (1985), Daniel (2002) and Daniels (2005).

Family Ranidae was represented by a single species Hylarana malabarica, commonly called as fungoid frog because they emit a powerful fungoid odour, resembling burnt rubber, under excitement. This species was generally found in forested land though it has been recorded in open area also, particularly

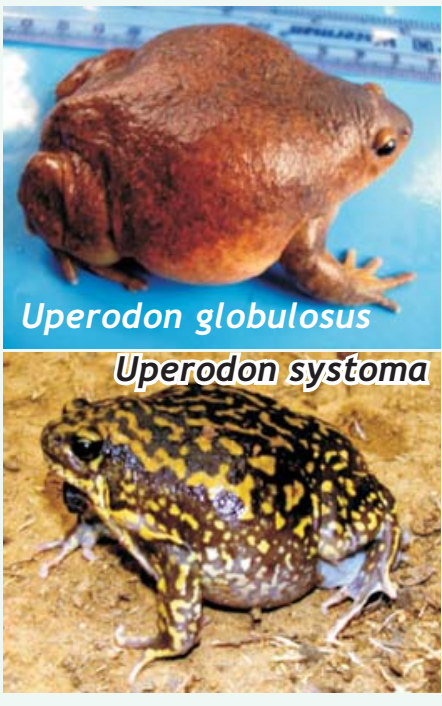

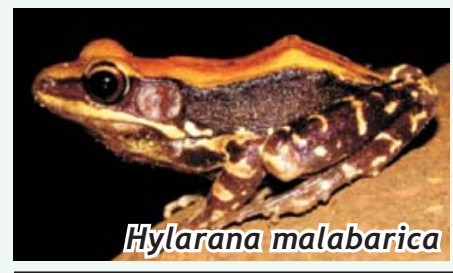

Ambient Science (2015) in the breeding season. It is semiarboreal but can spend subterranean life also. A large number of fungoid frogs was seen in the wet Kotumsar cave and dry but moist Dandak, and Kailash caves in Kanger Valley National Park including Aranyak cave in Darbha forest range. All these caves are located about $30 \mathrm{~km}$, south-west of Jagdalpur city. This 
particular species has already been designated as Cave frog of India (Biswas, 2014).

Family Rhacophoridae was represented by a single species Polypedates maculatus. This species was fairly well distributed in the study area, most of this arboreal and nocturnal species were observed on leaves or stems of plants, on walls, door frames and window panels inside houses. This species is generally an

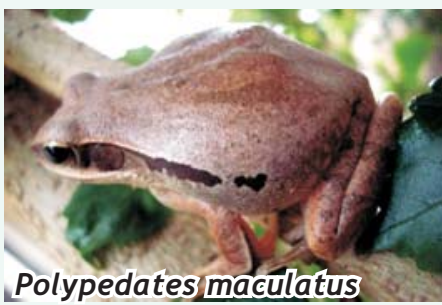
urban tree frog; however, it also occurs within secondary forests. The species has the peculiar habit of absorbing water under the skin, a habit also described by Daniel (2002).

Present Threats for Anurans in Bastar: survey of Indravati basin has so far resulted in the identification of sixteen species of frogs; however, presence of some more species could not be denied. Howfar threats of these species is concerned the exotic fish species like Gambusia and Tilapia (Orecohromis) which are in the present days most common species in india feeds on frog egg and tadpole and are mainly responsible to wipe out the frog populations from the water bodies of this region.

Even today the persistent demand of frog meat in Bastar area is also a threatening factor for anuran populations. Further, day by day the using of heavy amount of chemical fertilizers and pesticides in the paddy fields could not be denied as one of the major issue for declining the anuran population.Creation of awareness among the people for the conservation of amphibian species has become essential.

\section{Conclusion:}

Overall, the results of the present investigation suggest that there is much variation in the habitation of anuran species owing to external factors (anthropogenic stress, predation and chemical contamination) although located at the more or less same altitude and experiencing similar environmental factors.

In recent years due to rapid industrialization and urbanization, most of the open fields, which are natural breeding pools of many amphibians, are gradually vanishing. This is a threat to the future survival of rare frogs in their natural habitat. Therefore it is necessary to take steps for the conservation and incaptivity production of such species to increase their number in nature.

Acknowledgements:

I take this opportunity to extend my sincere and profound gratitude to Prof. M.L.Naik (Ret.), Pt. R.S.U., Raipur for his encouragement, guidance and valuable suggestions from inception to completion of the present work. Thanks are also due for Dr. Sushil Kumar Dutta, FNASc. (Ret.), North Orissa University, Baripada, Orissa for not only identifying and confirming various specimens but also for visiting Bastar with Dr. Pratyush P. Mohapatra, Scientist, WWF, working in Orissa for guidance at field level. Special thanks to Shri Vishvas Meshram, former Deputy Collector Jagdalpur, Mr. S. Venkatachalam I.F.S.(C.F.) former Director, Kanger Valley National Park, Bastar and Mr. Sunil Rathore (S.D.O.) former R.O. Koleng Forest Range for their unreserved helpduring field work. 


\section{References:}

Biju, S.D. (2008): Taxonomy-the tragedy of nameless extinction. The Hindu Survey of the Environment. 124-129p.

Biswas, J. (2010): Kotumsar Cave biodiversity: a review of cavernicoles and their troglobiotic traits. Biodivers Conserv., 19:275-289.

Biswas, J. (2014): Occurrence and Distribution of Cave Dwelling Frogs of Peninsular India.Ambient Sci.. 1(2): 17-25.

Biswas, J. \& Shrotriya, S. (2011): Dandak: a mammalian dominated cave ecosystem of India. Subterranean Biol. 8: 1-7.

Boulenger, G.A. (1882): Catalogue of the Batrachia Salientias. Caudata in the collection of the British Museum, London. Trustees of the British Museum, London. 2nd ed., xvi + 503pp.

Boulenger, G.A. (1890): The fauna of British India, including Ceylon and Burma, in Reptilia and Batrachia. Taylor and Francis, xviii+541pp.

Boulenger, G.A. (1920): A monograph of the south Asian, Papuan, Malayesian and Australian frogs of the genus Rana.Rec.Indian Mus. Calcutta:1-226. Comments: New species: Bufo fergusonii.

Chanda, S.K. (1995): Amphibia, pp. 71-75. In : Fauna of Conservation Areas No. 6: Fauna of Indravati Tiger Reserve. Zoological Survey of India.

Chanda, S.K. (2002): Handbook-Indian Amphibians, Zoological Survey of India, Calcutta : i-viii, 1-335 pp.

Chandra, K. \& Gajbe, P.U. (2005) An inventory of herpetofauna of Madhya Pradesh and Chhattisgarh. Zoos' print. 20(3): 1812-1819.

Daniel, J.C. (1963a): Field guide to the amphibians of western India. Part. I, L. Bom. nat. his. soc., 6o(2): 415-438.

Daniel, J.C. (1963b): Field guide to the amphibians of western India. Part. II. J. Bom. nat. his. soc., 60(3): 690-702.

Daniel, J.C. (1975): Field guide to the amphibians of western India. Part. III. J. Bom. nat. his. soc., 72(2): 506-522.

Daniel, J.C. (2002): The Book of Indian Reptiles and Amphibians. Bombay Natural History Society and Oxford University Press, Mumbai: i-viii, 1-238 pp.

Daniel, J.C. \& Sekar, A.G. (1989): Field guide to the amphibians of Western India. J. Bom. nat. his. soc., 86:194-202.

Daniel, J.C. \& Verma, K.K. (1963): Occurrence of the Ceylon Kaloula Kaloula pulchra taprobanica Parker （Family: Microhylidae) At Jagdalpur, Bastar District, M . P. J. Bom. nat. his. soc. 6o(3): 744-745.

Daniel, J.C. \& Selukar, T.G. (1963): Occurrence of the fungoid frog Rana malabarica (Bibron) at Jagdalpur, Bastar District M.P. L. Bom. nat. his. soc., 6o(3): 743-744.

Daniels, R.J.R. (2005): Amphibians of peninsular India. Universities Press, Hyderabad, i-xii, 1-268 pp.

Dinesh, K.P., Radhakrishnan, C., Gururaja, K.V., Deuti, K. \& Bhatta, G.K. (2009): A Checklist of Amphibia of India, Updated till August 2009 Online Version Zoological Survey of India.

Dutta, S.K. (1992): Amphibians of India: updated species list with distribution record. Hemadryad.17: 1-13.

Dutta, SK. (1997a) A new species of Fejervarya(Anura: Ranidae) from Orissa, India. Hamadryad 22: 1-8.

Dutta, S.K. (1997b): Amphibians of India and Sri Lanka (Checklist and Bibliography).Odyssey Publishing House, Bhubaneshwar, Orissa, India: i-xiii, 1-342.

Dutta, S.K. \& Pradhan, B. (1985) Burrowing specialization in anurans. Pranikee-J.Zool. Soc. Orissa, 6: 41-52.

Frost, D.R. (2009): AMPHIBIAN SPECIES OF THE WORLD: AN ONLINE REFERENCE. VERSION accessible at http://research.amnh.org/herpetology/amphibia/ American Museum of Natural History, New York, USA.

McCann, C. (1932) Notes on Indian batrachians. J. Bom. nat. his. soc., 36:152-18o.

Mohanty-Hejmadi, P. and SK. Dutta (1977) Breeding habits and developments of Rana cyanophlyctis Schneider. L. Bom. nat. his. soc., 76(2):291-296.

Parker, HW. (1934) A monograph of the frogs of the family Microhylidae. Trustees of the British Museum London. Viii + 208pp.

Sekar, A.G. (1992) Additions to the list of amphibian fauna of Goa. L. Bom. nat. his. soc., 89:134-135. 